\title{
Performance of concrete with the incorporation of waste from the process of stoning and polishing of glass as partial replacement of cement
}

\section{Desempenho de concretos com a incorporação de resíduo do processo de lapidação e polimento do vidro como substituto parcial ao cimento}
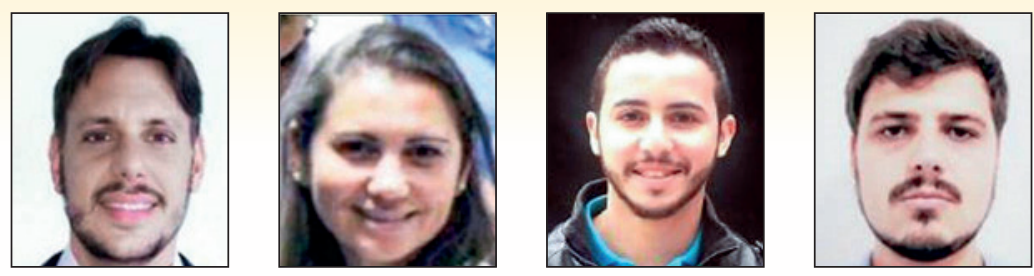

G. C. GUIGNONE a

gcgarquiteto@gmail.com

https://orcid.org/0000-0002-1007-8739

G. L. VIEIRA

geilma.vieira@gmail.com https://orcid.org/0000-0001-6148-3307

R. ZULCÃO a

robsonzulcao@gmail.com

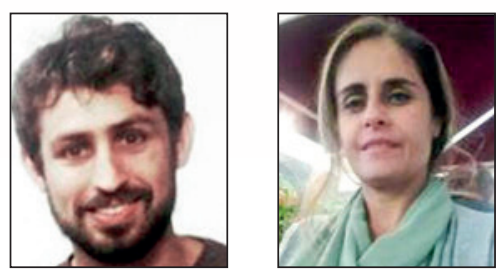

M. K. DEGEN a

maxdegen@hotmail.com

https://orcid.org/0000-0002-6453-797X

S. H. M. MITTRI

sergio-mittri@hotmail.com

https://orcid.org/0000-0001-6038-8463

C. R. TELES a

clauteles@hotmail.com

https://orcid.org/0000-0002-5639-389X

\section{Abstract}

The incorporation of waste glass as a partial replacement for cement in concrete can provide an alternative destination for the waste, reduce the consumption of cement (minimizing $\mathrm{CO}_{2}$ emissions and consumption of natural resources), and improve the concrete performance. Thus, this research evaluated the performance of concrete incorporating waste glass sludge (GS), resulting from the process of stoning and polishing of soda-lime flat glass, as a supplementary cementing material. Mechanical strength and durability properties were assessed through compressive strength, alkali-silica reactivity, electrical resistivity and chloride permeability, diffusivity and migration tests. Mixtures containing metakaolin (ME) were also evaluated. The results indicated that the use of the waste ground to an adequate size can replace up to $20 \%$ of cement. At this content, it caused a reduction of chloride penetration of over $80 \%$, reduced ASR and conserved compressive strength. The combination of waste with metakaolin replacing $20 \%$ of cement also improved all the concrete properties, increasing the compressive strength up to $12 \%$ at 28 days.

Keywords: waste glass. pozzolan. metakaolin. chloride. alkali-aggregate reaction.

\section{Resumo}

A incorporação de resíduos de vidro em concretos como substitutos parciais ao cimento pode proporcionar um destino alternativo aos resíduos, reduzir o consumo de cimento (minimizando as emissões de $\mathrm{CO}_{2}$ e o consumo de recursos naturais) e melhorar o desempenho do concreto. Assim, esta pesquisa avaliou o desempenho de concretos com a incorporação de lama de resíduo de vidro (GS), resultante do processo de lapidação e polimento de vidros planos sodo-cálcicos, como material cimentício suplementar. As propriedades de resistência mecânica e de durabilidade foram avaliadas por meio de testes de resistência à compressão, reatividade álcali-sílica, resistividade elétrica e permeabilidade aos íons cloreto por meio de mecanismos de transporte de difusividade e migração de cloretos. Misturas contendo metacaulim (ME) também foram avaliadas. Os resultados indicaram que o uso do resíduo de vidro moído, adotando-se dimensões de partículas adequadas, pode substituir até $20 \%$ de cimento. Proporcionando assim, uma redução na penetração de cloretos acima de $80 \%$, reduzindo a ASR e conservando a resistência à compressão. A combinação de resíduos de vidro com metacaulim, substituindo $20 \%$ do cimento, também melhorou todas as propriedades do concreto, aumentando a resistência à compressão em até $12 \%$ em 28 dias.

Palavras-chave: resíduo de vidro. pozolana. metacaulim. cloreto. reação álcali-agregado.

Universidade Federal do Espírito Santo, Civil Engineering Department, Vitória, ES, Brazil.

Received: 25 Jan 2019 • Accepted: 23 Oct 2019 • Available Online: 26 May 2020

匹ᄄ This is an open-access article distributed under the terms of the Creative Commons Attribution License 


\section{Introduction}

The increase of natural resources and energy consumption correlates with the increase of population. This has generated concerns regarding the finitude of resources, waste generation and gaseous emissions. Alternative technologies and waste reutilization emerge as possible solutions to these issues [1-4], the construction sector being of major importance due to its high consumption of energy and resources and waste generation. Portland cement used in concrete production has clinker as its main component, which is produced by burning limestone with other ingredients at high temperatures, consuming natural resources and emitting $\mathrm{CO}_{2}$. In the chemical reaction to dissociate 1 ton of limestone, $440 \mathrm{~kg}$ of $\mathrm{CO}_{2}$ is emitted, and only $560 \mathrm{~kg}$ goes into the clinker composition [5].

According to Shi and Zheng [6], among the urban solid wastes, glass can be considered the most suitable as a cement replacement due to its physical properties and chemical composition. Waste glass generation worldwide has not been precisely quantified, mainly due to the lack of data in several countries, such as those situated in the Middle East. Jani and Hogland [7] state that the world production of glass in 2007 was about 89.4 million tons, and it is expected to rise due to industrialization and improvement of the quality of life. Saito and Shukuya [8] estimate that for each $\mathrm{kg}$ of float glass produced, $1.73 \mathrm{~kg}$ of raw materials and $0.15 \mathrm{~m}^{3}$ of water are used. Additionally, due to the need for elevated temperatures (up to $1600^{\circ} \mathrm{C}$ ) to produce the glass, they estimate $16.9 \mathrm{MJ}$ of waste heat for each $\mathrm{kg}$ of glass sheets.

Several studies indicate that the use of glass powder (or waste glass) in concrete production can improve the mechanical and durability properties. Regarding the mechanical properties, an increase in concrete compressive strength after 56 days is noted when replacing $20 \%$ of cement by glass powder with particles size smaller than $20 \mu \mathrm{m}$ [9-11]. Using particle sizes between 75 and $100 \mu \mathrm{m}$, a strength loss is verified at the same replacement level [12-13]. For durability, an improvement in chloride penetration resistance is reported, by means of chloride migration tests, for the same replacement level [11-16]. It noted that the pozzolanic activity of the glass powder increases with grinding and that the ideal particle size should be smaller than $40 \mu \mathrm{m}$ for use as a partial replacement for cement [17]. Nevertheless, there is discussion regarding the use of materials with alkalis content above the normative limits for concrete production, as the alkalis can react with the siliceous compounds present in the reactive aggregates, causing deleterious expansive mechanisms in the hardened concrete [18]. Studies point out that the use of supplementary cementitious materials (SCM) can help reduce this mechanism called the alkali-silica reaction (ASR). The use of SCM can help to reduce the calcium hydroxide content in the pores solution by causing pozzolanic activity [11-12]. Research has also revealed that the particles size influences the occurrence of these reactions [12, 19].

There is little literature regarding the analysis of chloride penetration by different transport mechanisms and the ASR assessment of concrete mixtures with waste glass combined with metakaolin. Authors have mainly assessed the chloride penetration resistance by migration tests (rapid migration test - RMT) [11-20] and no diffusion by immersion tests have been performed. Thus, an evaluation of chloride resistance by different tests is regarded as relevant, due to the discussion related to the tests procedures and the diffusion coefficients obtained from chloride diffusion tests (bulk diffusion test - BDT) and migration tests (RMT) [2123]. Additionally, there is a lack of studies concerning the durability of concrete incorporating wastes from the process of stoning and polishing soda-lime flat glass (waste glass sludge). A study by Kim et al. [24] evaluated the use of glass stoning waste in concrete, aiming at improving the durability properties in freezing and thawing cycles. Improvements were noted in the compressive strength and chloride penetration resistance of mixtures combining $10 \%$ glass powder and $10 \%$ fly ash compared to those with only fly ash as SCM.

Regarding the use of glass sludge waste in concrete production, the literature is even scarcer. Pignaton [25] assessed the properties of concrete containing waste from the process of stoning of glass (without subsequent grinding) and noticed a reduction in compressive strength with the increase of partial cement replacement by waste. Furthermore, Lee et al. [26] replaced $20 \%$ of cement with the stoning glass waste and verified a decrease in the compressive strength of concrete at 28 days, while noticing an increase at 91 days.

Thus, due to its fine particle size, waste glass is considered as a viable option for incorporation into concrete, with little or no further processing (grinding). Therefore, this study aims to contribute to the studies related to the performance of concrete incorporating the waste generated by the stoning and polishing of soda-lime flat glass as a cement replacement, for the mitigation of environmental impact. The influence of further grinding of the waste prior to cement replacement was assessed. Mechanical and durability properties (chloride penetration by different transport mechanisms - migration and diffusion; ASR) were evaluated. Furthermore, metakaolin in isolation and combined with waste glass sludge was used for comparative purposes.

\section{Materials and experimental program}

\subsection{Materials}

High early-strength Portland cement, CPV-ARI (equivalent to CEM I $52.5 \mathrm{R}$ ) was used in this study. As high mineral additions content can influence test results, this cement was used as it is the commercially available cement in Brazil with the lowest percentage of additions (up to $5 \%$ limestone powder). Natural quartz sand and granitic coarse aggregate were used as aggregates in the mixtures. The coarse aggregate had maximum grain size of $19 \mathrm{~mm}$, true density of $2.77 \mathrm{~g} / \mathrm{cm}^{3}$, bulk density of $1.45 \mathrm{~g} / \mathrm{cm}^{3}$ and water absorption of $0.73 \%$. The fine aggregate had maximum grain size of $2.4 \mathrm{~mm}$, fineness modulus of 1.92 and true density of $2.57 \mathrm{~g} / \mathrm{cm}^{3}$. The physical and chemical characterization of cement, metakaolin (ME), glass sludge without grinding (GS1) and ground glass sludge (GS2) are presented in Table 1. Grinding of the waste glass was used to intensify the material reactivity.

Figure 1a shows the particle size gradation curve of GS1, GS2, cement and metakaolin used in the experimental program. Additionally, Figure $1 \mathrm{~b}$ presents the X-ray diffraction (XRD) of the ground waste, where an amorphous state can be verified, due to the absence of visible peaks in its spectrum. Studies have pointed out that the pozzolanic reactivity increases if more amorphous phases are present in the supplementary cementing materials $[27,28]$. 


\section{Table 1}

Physical and chemical properties of GS1, GS2, metakaolin and cement

\begin{tabular}{|c|c|c|c|c|}
\hline $\begin{array}{c}\text { Composition (\%), } \\
\text { by mass }\end{array}$ & $\begin{array}{l}\text { Glass sludge } \\
\text { (GS1) }\end{array}$ & $\begin{array}{l}\text { Ground glass } \\
\text { sludge } \\
\text { (GS2) }\end{array}$ & $\begin{array}{l}\text { Metakaolin } \\
\text { (ME) }\end{array}$ & Cement \\
\hline Silica $\left(\mathrm{SiO}_{2}\right)$ & 64.77 & 64.77 & 58.7 & 19.42 \\
\hline Alumina $\left(\mathrm{Al}_{2} \mathrm{O}_{3}\right)$ & 2.81 & 2.81 & 33.1 & 4.87 \\
\hline Iron oxide $\left(\mathrm{Fe}_{2} \mathrm{O}_{3}\right)$ & 0.44 & 0.44 & 1.8 & 2.93 \\
\hline Calcium oxide $(\mathrm{CaO})$ & 6.92 & 6.92 & 0.2 & 63.69 \\
\hline Magnesium oxide $(\mathrm{MgO})$ & 4.49 & 4.49 & 0.2 & 0.86 \\
\hline Sodium oxide $\left(\mathrm{Na}_{2} \mathrm{O}\right)$ & 19.36 & 19.36 & 0.2 & - \\
\hline Potassium oxide $\left(\mathrm{K}_{2} \mathrm{O}\right)$ & 0.11 & 0.11 & 1.8 & 0.8 \\
\hline Sulphur trioxide $\left(\mathrm{SO}_{3}\right)$ & 0.21 & 0.21 & 0.2 & 3.02 \\
\hline$\%$ retained \# 400 mesh & - & - & - & 2.2 \\
\hline$\%$ retained \# 325 mesh & 19.65 & 7.64 & 8.14 & - \\
\hline \% retained \# 200 mesh & 10.63 & 4.08 & 0.92 & - \\
\hline Average particle size $(\mu \mathrm{m})$ & 42.17 & 35.02 & 23.8 & 16.06 \\
\hline Median particle size - d50 $(\mu \mathrm{m})$ & 16.06 & 10.28 & 16.65 & 13.75 \\
\hline Specific gravity $\left(\mathrm{g} / \mathrm{cm}^{3}\right)$ & 2.51 & 2.51 & 2.55 & 3.07 \\
\hline Blaine specific surface area $\left(\mathrm{cm}^{2} / \mathrm{g}\right)$ & 6121 & 8015 & 18549 & 4751 \\
\hline
\end{tabular}

\subsection{Waste from the process of stoning and polishing of glass}

The glass powder used in this study is a waste originated in the process of stoning and polishing flat glass. It is obtained through the water recycling process, according to Figure 2. In summary, ducts crossing the glass manufacturing area collect the slurry that contains the water used in the stoning process along with the glass powder. This waste output is then conducted by pipes to reservoirs, where submerged pumps raise it to vertical silos for decantation (Figure 2b). Subsequently, the sludge (water and glass powder) is pumped to vertical silos, where chemical products (compounds of ethanol, oxides and polar solvents) are added for decantation. The excess water is then transported to another reservoir where is pumped back to the manufacturing process. Afterwards, the waste proceeds to the sludge mixer, and it is pumped to the filter press for dehydrating. The sludge is pressed, the excess water returns to the manufacturing process, and the final waste is obtained (Figure 2c). With this system, approximately 95 to $97 \%$ of the water is reused in the process [25].

The waste used in this study was obtained from a factory which generates around $290 \mathrm{~kg}$ of the final waste daily, totaling approximately 84 tons yearly. After collection, the waste was partially air dried, and then oven dried at $100{ }^{\circ} \mathrm{C}$ until mass constancy

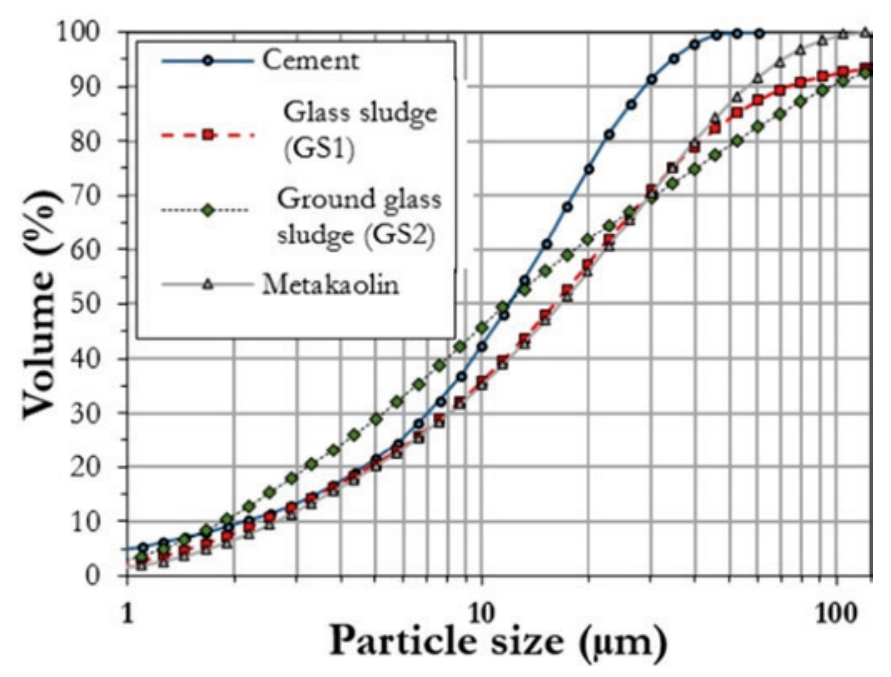

(a)

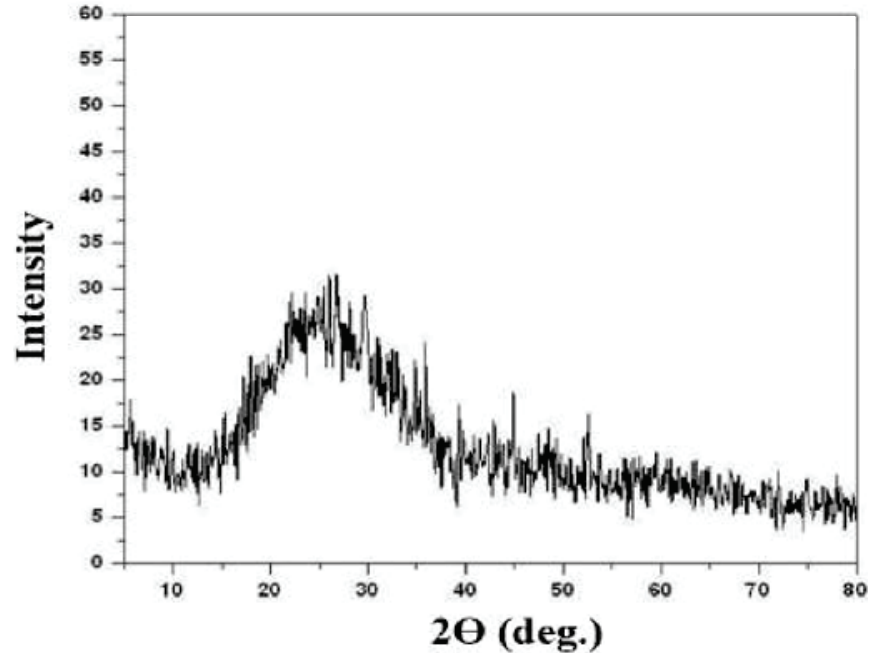

(b)

Figure 1

(a) Size gradation curve of cement, GS1, GS2 and metakaolin. (b) X-ray diffraction (XRF) of GS2 
Glass manufacturing process
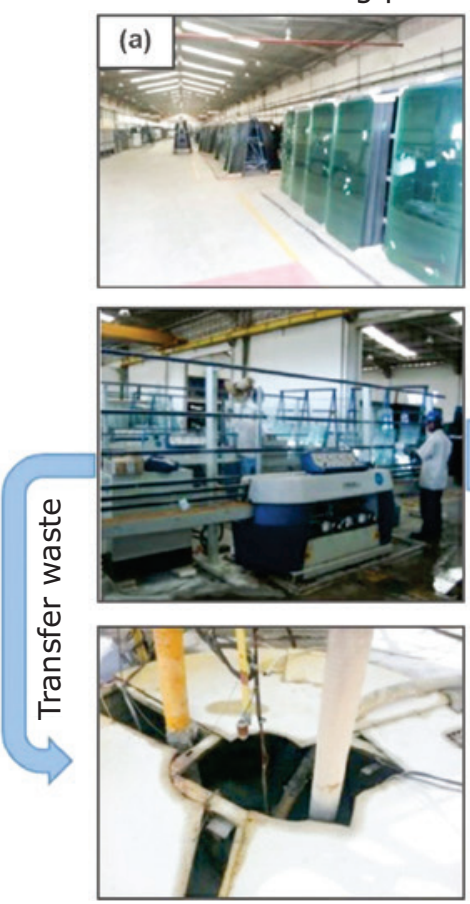
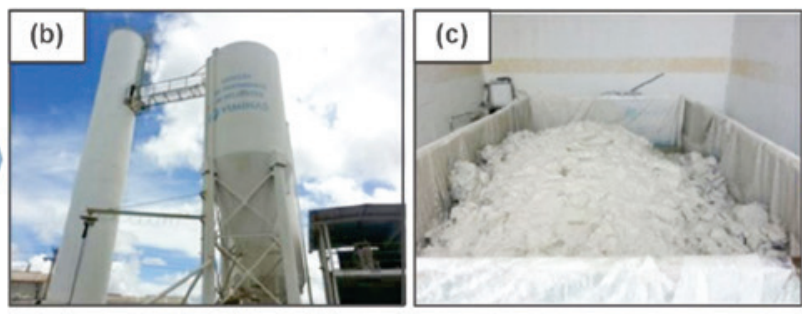

Sludge treatment for water recovery (to be reused in the stoning and polishing processes)
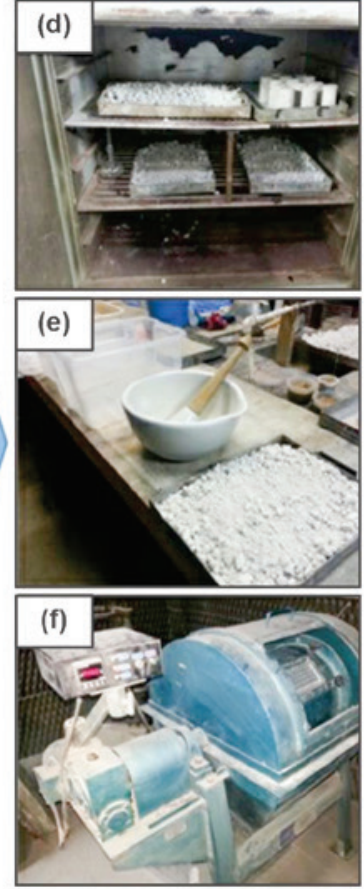

Oven drying, crushing and milling

\section{Figure 2}

(a) Glass before stoning and polishing; (b) Silo for decantation; (c) Final waste after filter press;

(d) Oven drying; (e) Crushing for breaking the lumps, GS1; (f) Ball mill for grinding, GS2

(Figure 2d). Subsequently, the waste was crushed to break the lumps using a ceramic mortar and pestle (Figure 2e). Additionally, aiming to intensify its reactivity, the waste was also ground. For the grinding process, a ball mill was used, composed of steel balls of $40 \mathrm{~mm}$ diameter and $0.278 \mathrm{~kg}$. The internal diameter of the mill was $380 \mathrm{~mm}$ with a volume of 47 litres with the capacity of $14 \mathrm{~kg}$ per batch (Figure 2f). Thus, two types of glass powder were produced: GS1, without grinding, and GS2, ground.

\subsection{Pozzolanic activity}

The premises from the ABNT NBR 12653 [29] standard were used to assess the pozzolanic activity of the materials, where limits re- garding the physical and chemical properties are established, as per Table 2. The standard classifies the materials in three classes ( $\mathrm{N}, \mathrm{C}$ and $\mathrm{E}$ ) according to their nature. The glass waste fits in class $\mathrm{E}$, comprising percentage amounts of $\mathrm{SiO}_{2}+\mathrm{Al}_{2} \mathrm{O}_{3}+\mathrm{Fe}_{2} \mathrm{O}_{3}$ greater than $50 \%$, whereas metakaolin fits into class $\mathrm{N}$, comprising percentage amounts greater than $70 \%$ for the same compounds. The method according to Luxán et al. [30] was also used for complementing the information regarding the materials' pozzolanic activity. This method, which can be rapidly executed, is based on measuring the conductivity of a saturated solution with calcium hydroxide, before and after adding the potential pozzolanic material. According to Rodrigues [31], variation of the conductivity occurs due to the pozzolanic reaction with the ions $\mathrm{Ca}^{2+}$ and $(\mathrm{OH})$; that is,

Table 2

Limits for classification of pozzolanic materials according to NBR 12653 [29]

\begin{tabular}{|c|c|c|c|c|c|}
\hline Properties & $\begin{array}{c}\text { Limits } \\
\text { ABNT NBR } \\
12653[29] \\
\text { Class E }\end{array}$ & $\begin{array}{c}\text { Limits } \\
\text { ABNT NBR } \\
12653[29] \\
\text { Class N }\end{array}$ & $\begin{array}{l}\text { Glass sludge } \\
\text { (GS1) } \\
\text { (class E) }\end{array}$ & $\begin{array}{l}\text { Ground glass } \\
\text { sludge (GS2) } \\
\text { (class E) }\end{array}$ & $\begin{array}{l}\text { Metakaolin (ME) } \\
\quad(\text { class } N \text { ) }\end{array}$ \\
\hline $\begin{array}{c}\text { Fineness by sieve \#325 } \\
(45 \mu \mathrm{m}) \\
\text { (\% retained) }\end{array}$ & $<20$ & $<20$ & 19.65 & 7.64 & 8.14 \\
\hline $\begin{array}{l}\text { Pozzolanic activity with } \\
\text { lime (MPa) [32] }\end{array}$ & $\geq 6$ & $\geq 6$ & 4.14 & 6.28 & 11.53 \\
\hline $\begin{array}{l}\text { Pozzolanic activity with } \\
\text { cement (\%) [33] }\end{array}$ & $\geq 90$ & $\geq 90$ & 83 & 90 & 137 \\
\hline $\mathrm{SiO}_{2}+\mathrm{Al}_{2} \mathrm{O}_{3}+\mathrm{Fe}_{2} \mathrm{O}_{3}(\%)$ & $\geq 50$ & $\geq 70$ & 68.02 & 68.02 & 93.6 \\
\hline $\mathrm{SO}_{3}(\%)$ & $\leq 5$ & $\leq 4$ & 0.21 & 0.21 & 0.2 \\
\hline Loss on ignition (\%) & $\leq 6$ & $\leq 10$ & 0.55 & 0.55 & 2.5 \\
\hline $\begin{array}{l}\text { Available alkalis in } \\
\mathrm{Na}_{2} \mathrm{O}_{\mathrm{eq}}{ }^{*}(\%)\end{array}$ & $\leq 1.5$ & $\leq 1.5$ & 19.43 & 19.43 & 1.38 \\
\hline
\end{tabular}

$* \mathrm{Na}_{2} \mathrm{O}_{\text {eq }}=\mathrm{Na}_{2} \mathrm{O}+0.658 \mathrm{~K}_{2} \mathrm{O}$ 
the pozzolan reduces the quantity of free ions in the solution and, consequently, diminishes its conductivity. From the difference of conductivity, it was possible to classify the material according to its pozzolanic activity, where materials which presented a variation of conductivity above $0.4 \mathrm{mS} / \mathrm{cm}$ can be classified as pozzolans. Figure 3 shows that the ground glass sludge (GS2), as well as metakaolin, can be classified as materials containing pozzolanicity materials according to the method of Luxán et al. [30]. It is also possible to compare the materials used in this research with other materials commonly used in concrete structures, such as: ornamental rock residues and active silica.

It can be observed that the glass powder did not comply with the standard ABNT NBR 12653 [29] regarding the available alkalis content, presenting significantly higher values (Table 2 ). This observation motivated the execution of tests to assess the ASR, which can cause expansive mechanisms and concrete cracking. The ASR occurs during the hydration process, due to the reaction between reactive aggregates and the alkalis present in the cement and glass powder [14]. Furthermore, it was noted that the GS1 did not fulfill the pozzolanic activity tests with lime [32] and cement [33], fact that was corroborated by the Luxán et al. [30] method. Therefore, a preliminary study was performed to assess the necessary grinding time in a ball mill. The required time reached was $2 \mathrm{~h}$, reducing the retained percentage in sieve \# $325(45 \mu \mathrm{m})$ from 19.65 to $7.64 \%$ (maximum reduction obtained) (Figure $4 a$ ). The GS2 (Figure 4b) and GS1 aspect (Figure 4c) are also presented. Figures $4 \mathrm{~d}$ and $4 \mathrm{e}$ show the microscopic analysis of the ground residue where its angular geometry and particle sizes ranging from $2 \mu \mathrm{m}$ to $10 \mu \mathrm{m}$ can be identified.

After this process, the resulting product was a ground waste, called GS2, finer than metakaolin, which complied with the required limits to be classified as a pozzolanic material according to all tests performed $[30,32,33]$ (Table 2).

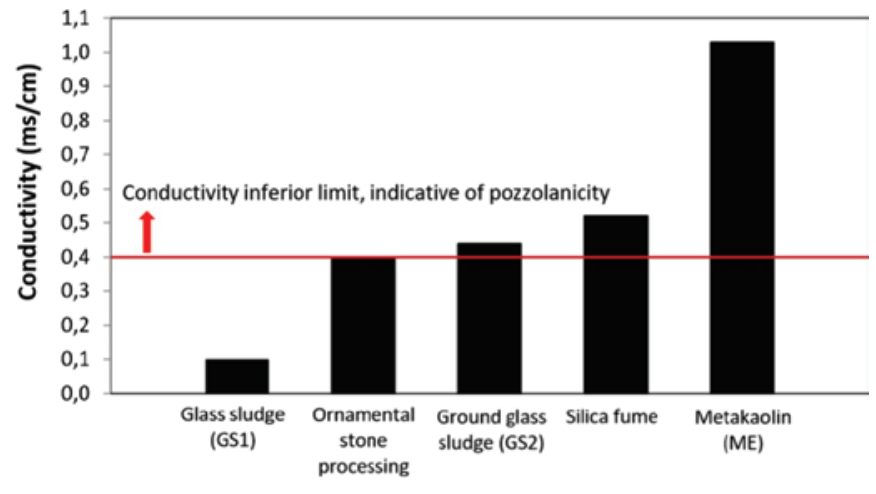

Figure 3

Pozzolanicity test as according to Luxán et al. [30] for the materials used in this study (GS1, GS2, ME) and other similar materials
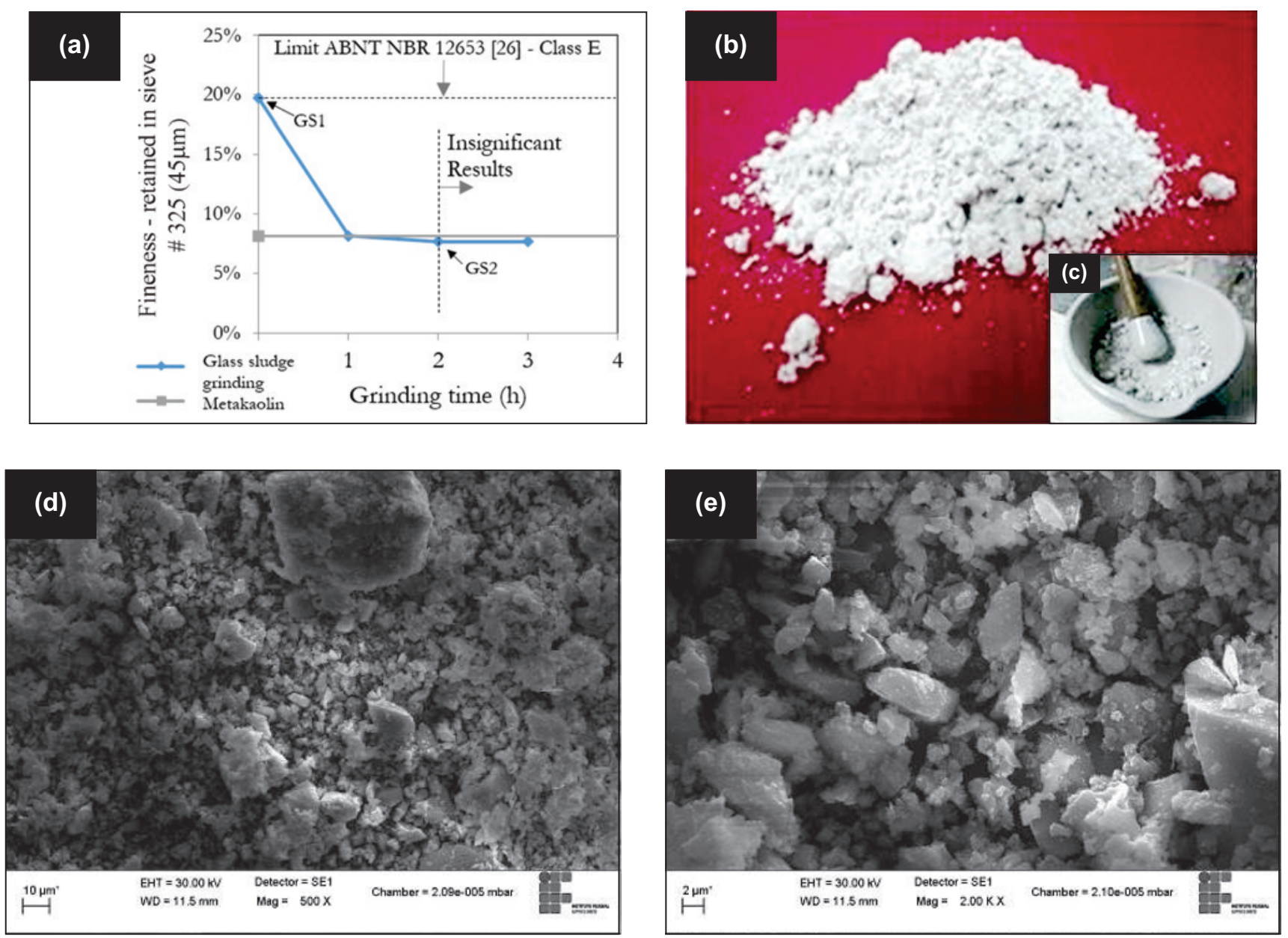

\section{Figure 4}

(a) Waste grinding time study; (b) GS2 (ground sludge), (c) GS1 (without grinding), (d) GS2 micrograph 500x; and (e) GS2 micrograph 2000x 


\subsection{Specimens preparation}

Mixtures containing 10 and $20 \%$ of glass sludge waste as partial substitute for cement (by volume) were used, adopting the waste without grinding (GS1) and after grinding (GS2) (Table 3). The cement replacement by metakaolin (ME) was also evaluated at the same contents, for comparative reasons, and the metakaolin combined with both glass powders (GS1ME and GS2ME) (Table 3) with aim of intensifying the mechanical and durability properties. The water/cementitious materials ratio $(w / c m)$ used was 0.60 , this being the highest accepted in the standard ABNT NBR 6118 [34] in urban applications. Furthermore, at this $\mathrm{w} / \mathrm{cm}$ ratio, a concrete of high porosity could be obtained, making it easier assess the possible pore-filling effects of the cement replacement by waste glass. Since the density of the waste glass powder and metakaolin is less than that of the cement, a volumetric compensation was used. It is important to note that the amount of water was maintained from the control mixture, considering the water/ cement ratio of 0.60 , changing the water/binder ratio for the other mixtures thereafter. The dosage method adopted was the IPT-EPUSP Method. Cylindrical specimens of $100 \times 200$ $\mathrm{mm}$ (diameter $\mathrm{x}$ height) were prepared, according to standard ASMT C192 [35], and cured in a moist chamber with relative humidity higher than $95 \%$ and temperature of $23 \pm 2$ ${ }^{\circ} \mathrm{C}$, until the testing day. The concrete fresh properties were assessed using slump test, according to ASMT C143 [36], and density measurement, according to ASMT C138 [37]. The slump value used for the control mixture was $200 \pm 10 \mathrm{~mm}$. This value, from the batching and consistency study, was adopted to compensate the reduction of the slump caused by the incorporation of fine and not immediately reactive materials (metakaolin and glass powder). Thereby, an appropriate workability was obtained for the preparation of specimens, since the use of superplasticizer was not considered for the study in order to not add new variables that might hamper the results identification.

\subsection{Methods}

\subsubsection{Mechanical strength tests}

The specimens were cured in a moist chamber until the testing ages of 28, 56 and 91 days. The upper and lower parts were polished for levelling, and then the specimens were submitted to the compressive test, according to standard ABNT NBR 5739 [38].

\subsubsection{Rapid chloride permeability test (RCPT)}

The rapid chloride permeability test (RCPT) was idealized by Whiting [39], and it is recommended by standard ASTM C1202 [40]. For each mixture, three specimens $-50 \mathrm{~mm}$ thick and 100 $\mathrm{mm}$ in diameter, extracted from the central part of the single original cylinder specimen - were tested at 28 and 91 days. The test consisted in exposing one side of the specimen to a sodium chloride solution ( $3 \% \mathrm{NaCl}$ by mass) and the other to a sodium hydroxide solution $(0.3 \mathrm{~N} \mathrm{NaOH})$. In each solution, a conducting copper electrode was introduced, and connected to a $60 \mathrm{~V} \pm 0,1$ $\checkmark$ source, creating an electrical current that induced the chlorides to migrate through the concrete specimen. Amperage readings were taken every $30 \mathrm{~min}$, totaling $6 \mathrm{~h}$ of testing. The sum of the electrical current by time, expressed in coulombs, specified the total charge passed through the specimen, indicating the chloride penetration resistance of the concrete.

\subsubsection{Rapid migration test (RMT)}

Proposed by Luping and Nilsson [41] and consolidated in the standard NT BUILD 492 [42], this method uses as procedures the potential difference and a colorimetric indicator (spray of $\mathrm{AgNO}_{3}-0.1 \mathrm{M}$ ). It provides quantitative data on the final chloride penetration depth and chloride diffusion coefficient. Specimens $50 \mathrm{~mm}$ thick and 100 $\mathrm{mm}$ in diameter, extracted from the central part of the single original cylinder specimen, were tested at 56 and 91 days. The specimens were exposed to sodium chloride solution $(2 \mathrm{~N} \mathrm{NaCl})$ on one side

\section{Table 3}

Mixture proportions for $1 \mathrm{~m}^{3}$ of concrete

\begin{tabular}{|c|c|c|c|c|c|c|c|c|c|}
\hline $\begin{array}{c}\text { Mix } \\
\text { design }\end{array}$ & $\begin{array}{c}\text { Cement } \\
\text { replacement } \\
(\%) \\
\text { (by volume) }\end{array}$ & $\begin{array}{l}\text { Cement } \\
\left(\mathrm{kg} / \mathrm{m}^{3}\right)\end{array}$ & $\begin{array}{c}\text { Glass } \\
\text { sludge } \\
(\mathrm{GS1}) \\
\left(\mathrm{kg} / \mathrm{m}^{3}\right)\end{array}$ & $\begin{array}{l}\text { Ground } \\
\text { glass } \\
\text { sludge } \\
(\mathrm{GS} 2) \\
\left(\mathrm{kg} / \mathrm{m}^{3}\right)\end{array}$ & $\begin{array}{l}\text { Metakaolin } \\
(\mathrm{ME}) \\
\left(\mathrm{kg} / \mathrm{m}^{3}\right)\end{array}$ & $\begin{array}{c}\text { Fine } \\
\text { aggregates } \\
\left(\mathrm{kg} / \mathrm{m}^{3}\right)\end{array}$ & $\begin{array}{c}\text { Coarse } \\
\text { aggregates } \\
\left(\mathrm{kg} / \mathrm{m}^{3}\right)\end{array}$ & $\begin{array}{c}\text { Mixture } \\
\text { density } \\
\left(\mathrm{kg} / \mathrm{m}^{3}\right)\end{array}$ & $\begin{array}{c}\text { Water } \\
\text { content } \\
\left(\mathrm{kg} / \mathrm{m}^{3}\right)\end{array}$ \\
\hline Control & 0 & 302.85 & - & - & - & 875.24 & 1133 & 2420 & 181.71 \\
\hline GS1-10 & 10 & 272.57 & 24.77 & - & - & 875.24 & 1133 & 2402 & 181.71 \\
\hline GS1-20 & 20 & 242.28 & 49.57 & - & - & 875.24 & 1133 & 2371 & 181.71 \\
\hline GS2-10 & 10 & 272.57 & - & 24.77 & - & 875.24 & 1133 & 2391 & 181.71 \\
\hline GS2-20 & 20 & 242.28 & - & 49.57 & - & 875.24 & 1133 & 2430 & 181.71 \\
\hline ME-10 & 10 & 272.57 & - & - & 25.17 & 875.24 & 1133 & 2396 & 181.71 \\
\hline ME-20 & 20 & 242.28 & - & - & 50.30 & 875.24 & 1133 & 2396 & 181.71 \\
\hline GS1ME-10 & 10 & 272.57 & 12.42 & - & 12.72 & 875.24 & 1133 & 2423 & 181.71 \\
\hline GS1ME-20 & 20 & 242.28 & 24.77 & - & 25.17 & 875.24 & 1133 & 2409 & 181.71 \\
\hline GS2ME-10 & 10 & 272.57 & - & 12.42 & 12.72 & 875.24 & 1133 & 2409 & 181.71 \\
\hline GS2ME-20 & 20 & 242.28 & - & 24.77 & 25.17 & 875.24 & 1133 & 2412 & 181.71 \\
\hline
\end{tabular}


and on the other to sodium hydroxide solution $(0.3 \mathrm{~N} \mathrm{NaOH})$. The test duration and the voltage adopted depended on the initial passing current reading in the concrete specimen when applying a different potential of $30 \mathrm{~V}$. Usually, the test can last from $24 \mathrm{~h}$, for ordinary concrete, to $96 \mathrm{~h}$, for high performance concrete. To calculate the apparent chloride ion migration coefficient, Equation 1 was used.

$D_{\text {nssm }}=\frac{0.0239(273+\mathrm{T}) \mathrm{L}}{(\mathrm{U}-2) \mathrm{t}}\left(X_{d}-0.0238 \sqrt{\frac{(273+\mathrm{T}) L x_{d}}{(\mathrm{U}-2)}}\right)$

Where: $D_{n s s m}$ is the non-steady-state migration coefficient multiplied by $10-12\left(\mathrm{~m}^{2} / \mathrm{s}\right)$; $U$ is the absolute value of the applied potential $(\mathrm{V})$; $\mathrm{T}$ is the average value of the initial and final temperatures in the anolyte solution $\left({ }^{\circ} \mathrm{C}\right)$; $\mathrm{L}$ is the thickness of the specimen $(\mathrm{mm})$ $x_{d}$ is the average value of the chloride penetration depth $(\mathrm{mm})$, and $\mathrm{t}$ is the test duration (h).

\subsubsection{Bulk diffusion test (BDT)}

The method for determining the apparent chloride diffusion coefficient on cementitious mixtures by bulk diffusion is based on the NT BUILD 443 [43] and consists in keeping the concrete specimens immersed in a chloride solution $(165 \mathrm{~g}$ of $\mathrm{NaCl}$ by litre) to induce accelerated diffusion mechanisms. The immersed test specimens (100 $\mathrm{mm}$ thick and $100 \mathrm{~mm}$ in diameter) were placed in a hermetically sealed plastic container, the solution being agitated weekly. The specimens were cured for 28 days in a moist chamber and subsequently immersed in the solution for 60,120 and 180 days. The chlorides profile was obtained by milling the material in layers parallel to the exposed surface. The thickness of the layers was adjusted according to the expected chloride profile, such that at least six places encompassed the profile between the exposed surface and the depth reached by the chlorides. The content of chloride soluble in acid in the specimens was determined according to NT BUILD 208 [44]. The test results, superficial chlorides concentration $\left(C_{s}\right)$ and non-steady-state chlorides diffusion coefficient $\left(D_{n s}\right)$ - also entitled chloride apparent diffusion coefficient $\left(D_{a}\right)$ [21] - were determined by adjusting Equation 2 for the chlorides content measured, using a linear regression analysis according to the least squares.

$C_{(x, t)}=C_{s}-\left(C_{s}-C_{i}\right) \cdot \operatorname{erf}\left(x / \sqrt{4 \cdot D_{a} \cdot \mathrm{t}}\right)$

Where: $C(x, t)$ (mass, \%) is the chlorides concentrations, measured at the depth $x$ at the exposure time $t$; Cs (mass, \%) is the boundary condition of the exposed surface; $\mathrm{Ci}$ (mass, \%) is the initial chlorides concentration measured; $x$ is the depth below the exposed surface $(\mathrm{m})$; $\mathrm{Da}$ is the chloride apparent diffusion coefficient $\left(\mathrm{m}^{2} / \mathrm{s}\right)$; $\mathrm{t}$ is the exposure time (s); erf is the Gauss error function.

\subsubsection{Alkali-silica-reaction (ASR) - expansion measurement}

This test provides means of detecting the alkali-silica reactivity potential in concrete, which can cause harmful expansion mechanisms and deleterious processes, such as concrete cracking. Three prismatic specimens $(25 \times 25 \times 285 \mathrm{~mm})$ were used for each mixture, as according to ABNT NBR 15577-4 [45]. The specimens were demolded $24 \mathrm{~h}$ after their casting, and submerged in water at $80^{\circ} \mathrm{C}$ for $24 \mathrm{~h}$. Subsequently, they were submerged in a solution of

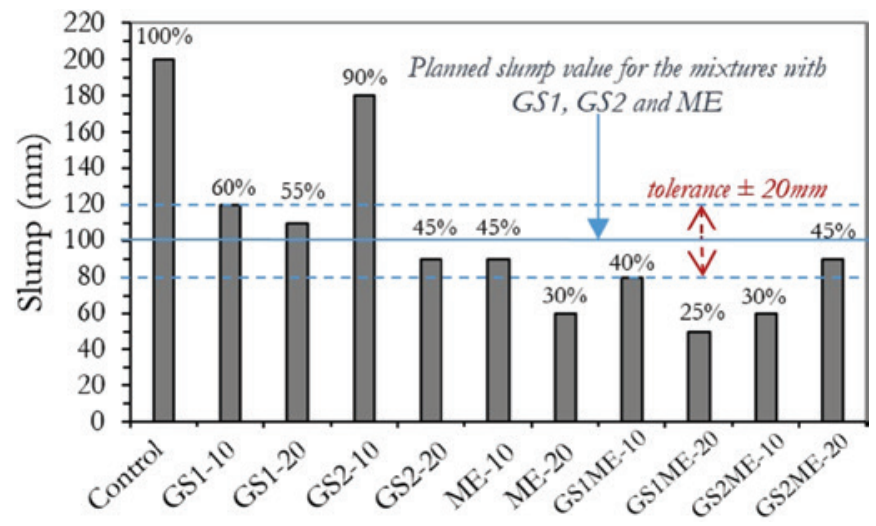

Figure 5

Slump values of the analyzed concrete mixtures

$\mathrm{NaOH}(1 \mathrm{~N})$ at $80^{\circ} \mathrm{C}$ and their initial lengths were registered. During 30 days, length readings were performed with the frequency of 3 days. The mentioned standard considers that if the expansion is higher or equal to $0.19 \%$ at 30 days, the aggregate is considered potentially reactive.

\section{Results and discussions}

\subsection{Slump tests}

The Figure 5 presents the slump values of the concrete mixtures. By using the glass sludge without grinding (GS1) and after grinding (GS2) there is a reduction in the slump value in comparison with the control mixture, as also found in other studies [46-48]. However, it was still an adequate workability $(100 \pm 20 \mathrm{~mm})$ to produce the concrete specimens and for the conventional applications of reinforced concrete, placed without pumping (ABNT NBR 8953 [49]). The use of materials with elevated superficial area and which do not react immediately in the mixture increases the demand for water in the fresh concrete. Thus, the use of very fine materials, as it is the case of the glass powder (average particle size 35-45 $\mu \mathrm{m}$ ) used in this study, confirms this mentioned effect, which can also be related to the poor geometry of the waste glass.

According to Ismail and Al-Hashmi [46], the reduction in the slump value can also be attributed to the geometry of the glass powder, resulting in a lower fluidity of the mixtures. Furthermore, mixtures with glass powder (GS1 and GS2) presented higher slump value than those mixtures that used metakaolin, indicating the lower demand for water of the glass sludge compared to metakaolin.

\subsection{Mechanical strength tests}

A compressive strength loss was identified at 28 days by replacing the cement by GS1 (Figure 6), as also verified in previous studies $[10-13,25]$. Nevertheless, the concrete using the ground waste at 10 and $20 \%$ cement replacement (GS2-10 and GS2-20), presented similar values to the control mixture, without significant statistical variation. It is also observed that the combination of the glass sludge waste with metakaolin, at $10 \%$ cement replacement 


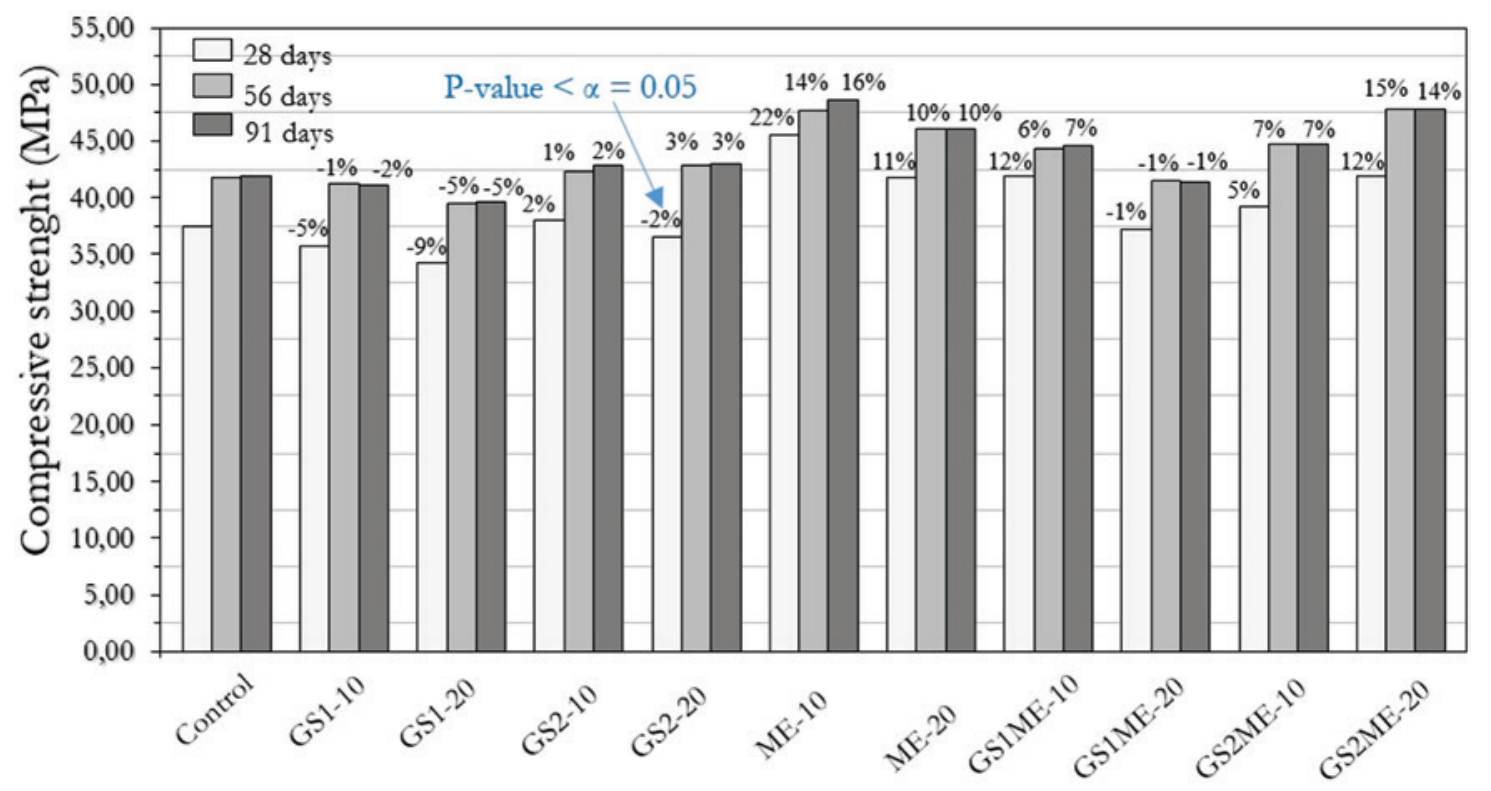

\section{Figure 6}

\section{Concrete compressive strength results}

each (GS2ME-20), presented an increase in compressive strength of $12 \%$ at 28 days, compared to the control mixture. Moreover, the positive effect of using glass powder can be seen at more advanced ages. At 56 and 91 days, the mixture with $20 \%$ ground glass powder (GS2-20) had results slightly higher than those of the control mixture. These results can be explained by the physical effect of pore-filling, where the empty pores left by the cement paste are filled by the glass particles, reducing the porosity, and contributing to the retention of the mixture water, enhancing the cement hydration process. Another process that may have contributed to the compressive strength gain is the possible pozzolanic effect of the glass waste. This possible chemical reaction between the glass powder and the cement (due to the formation of more

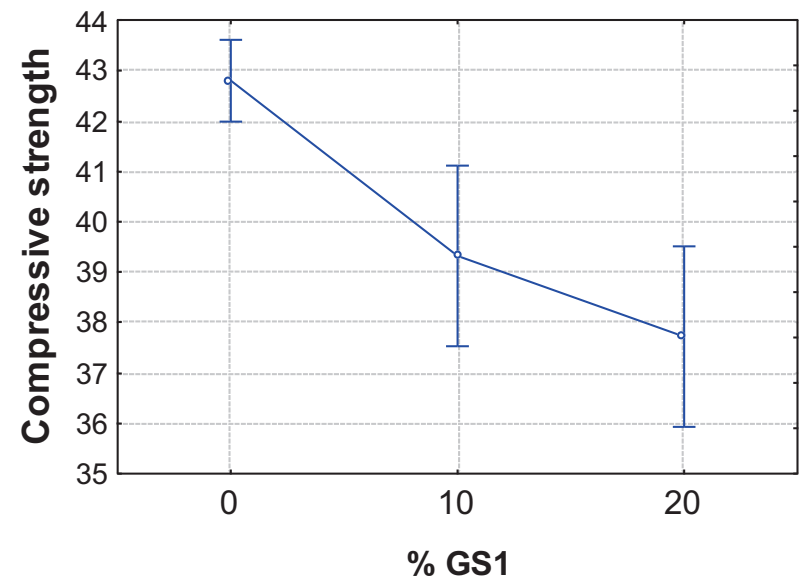

(a) stable compounds, such as the production of $\mathrm{C}-\mathrm{S}-\mathrm{H}$ originated from the reaction of calcium hydroxide and water) diminishes the empty spaces in the transition zone between the paste and the aggregates. Moreover, the GS2ME-20 presented superior values to that of the control mixture at all ages, and at 56 and 91 days, its values were similar to the mixture containing only metakaolin as a cement replacement, at $20 \%$ (ME-20). Thus, replacing the use of $10 \%$ metakaolin by glass waste is justified, promoting also possible economic and environmental aspects.

The ANOVA showed that there is a statistically significant $(p$-value $<0.05)$ reduction in the compressive strength as the glass sludge without grinding (GS1) content increases (Fig. 7a). Thus, initially indicating that the cement replacement by glass powder

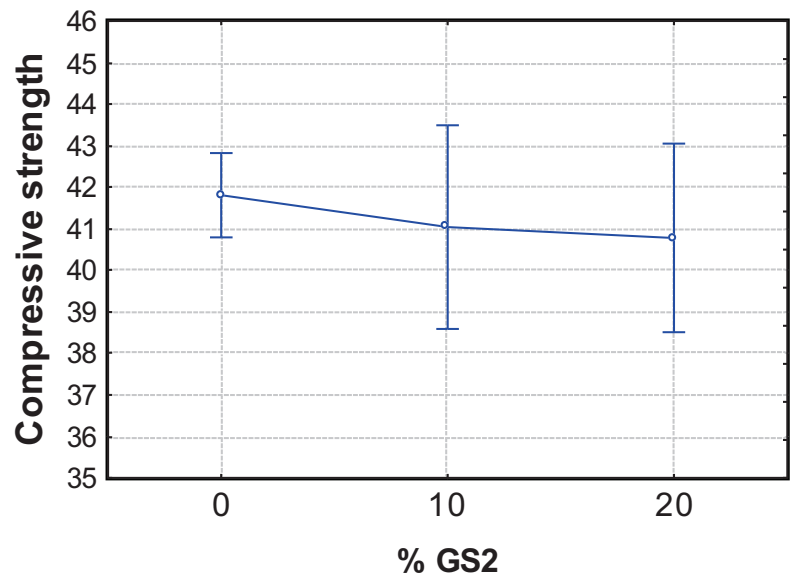

(b)

Figure 7

Statistical analysis of concrete with glass wastes. (a) mixtures with GS1 (b) mixtures with GS2 
Table 4

Statistical analysis of the compressive strength of concrete with GS2

\begin{tabular}{ccccccc}
\hline Factors & SS & DF & MS & F & p-value & Results \\
\hline GS2 content & 10.30 & 2 & 5.15 & 0.447 & 0.641849 Non-Significant \\
Age & 199.92 & 2 & 99.96 & 8.676 & 0.000550 & Significant \\
Error & 610.66 & 53 & 11.52 & - & - & - \\
\hline
\end{tabular}

without grinding did not cause a positive effect on the compressive strength. This is possibly due to the non-pozzolanic effect of the material (as observed in the pozzolanic activity tests - Table 2), combined with the fact the pore-filling effect was not sufficient to compensate the strength loss caused by the cement content reduction. It became necessary the identification of which treatments presented the variation; thus, the Tukey's test verified that the GS1 provided similar results to that of the control mixture. Therefore, indicating that it is possible to replace the cement by the GS1 without reducing the concrete strength, at up to $10 \%$, whereas at $20 \%$ replacement, a loss in compressive strength is verified. Additionally, using this statistical analysis to the GS2, it is noted that there is no significant difference between the concrete with and without the waste, since the GS2 content in the compressive strength presented p-value of 0.642 (> 0.05) (Fig. 7b and Table 4). Hence, it is possible to replace the cement by up to $20 \%$ of ground glass powder without negative effects in the compressive strength. This performance can be justified due to the pozzolanic reaction with the cement hydrated compounds, as identified in the pozzolanic activity tests performed in the ground waste (Table 2).

\subsection{Rapid chloride permeability test (RCPT)}

The use of glass powder in the contents of 10 and $20 \%$ increased the chloride penetration resistance of the mixture, by reducing the total charge passed (Figure 8), as noted in previous studies [11-16]. It is noted that both GS1, by the pore-filling effect, and GS2, by the pore-filling and the possible pozzolanic activity effect, produced a reduction in the total charge passed in the mixtures in comparison with the control, being the GS2 the most effective. The mixture with $10 \%$ glass sludge without grinding (GS1-10) did not reach a moderate level of chloride penetrability; nevertheless, it reduced the charge passed by 13 and $30 \%$ at 28 and 91 days, respectively, in comparison with the control. For $20 \%$ content (GS1-20), at 91 days it is verified a reduction of $83 \%$ compared to the control, being equivalent to the reduction obtained by the mixtures with ground waste (GS2-20, with $80 \%$ reduction) and metakaolin (ME-10, with $84 \%$ reduction, and ME-20, with $79 \%$ ). Figure 8 presents the qualitative classification used by the test standard and classifies GS1ME-20 and ME-10 as of very low chloride penetrability level, a significant reduction from the high level observed for the control mixture. This may be due to the combined effect of the metakaolin pozzolanic activity and the pore-filling effect caused by the waste. Furthermore, at $10 \%$ glass powder, the chloride resistance is improved with the grinding of the glass waste (GS2-10), and the increase of glass powder content also improves the chloride resistance.

According to the qualitative assessment proposed by Gjørv [50], the GS1-10 did not reach a moderate resistance to chloride

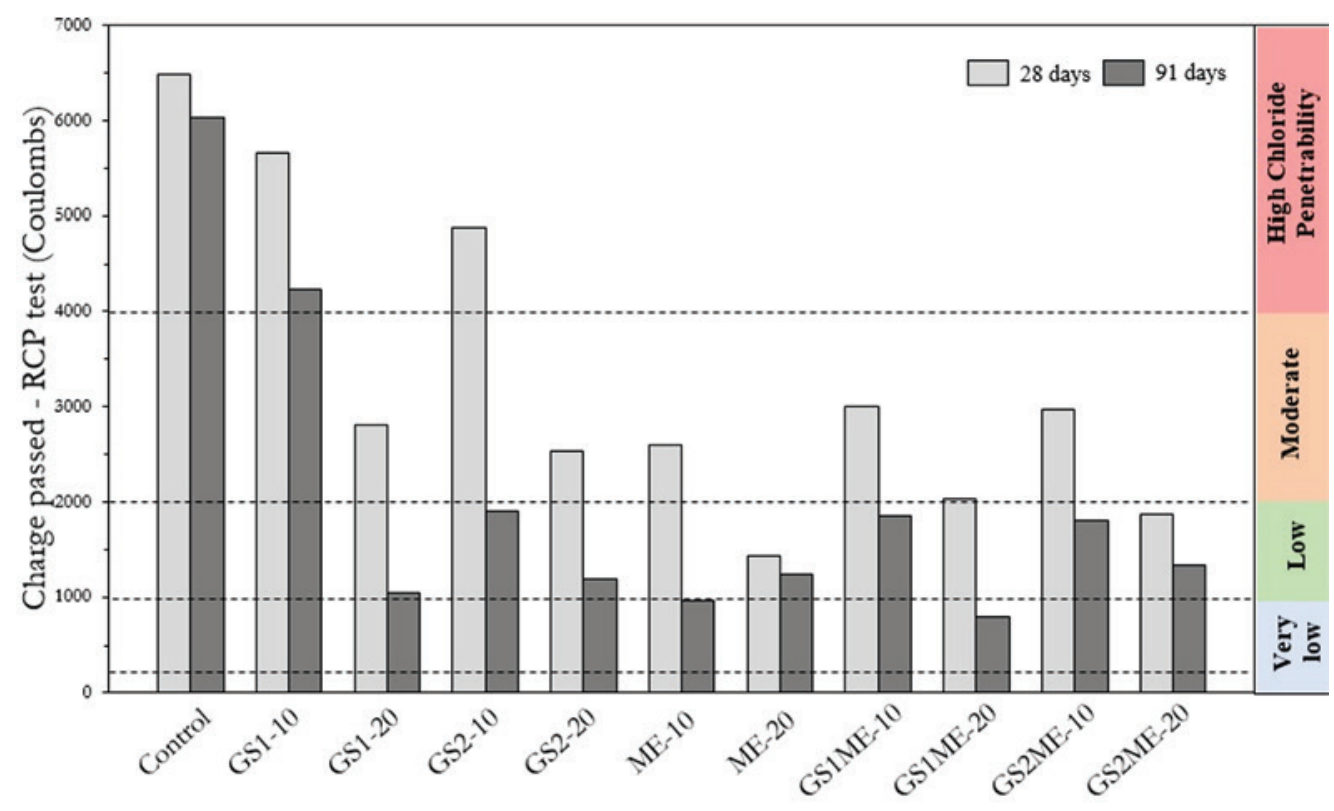

Figure 8

Total charge passed results and chloride resistance classification 
penetration (Figure 9), corroborating the results from total charge passed (ASTM C 1202 [40]). Thus, to improve the resistance to chloride penetration with $10 \%$ glass sludge waste addition, it was needed to grind the material (GS2-10), or to use it in combination with $10 \%$ metakaolin (GS1ME-20), replacing $20 \%$ of cement. The increase of glass sludge content to $20 \%$ (GS1-20) provided improvements in chloride resistance, advancing the classification to high chloride resistance at 56 days and very high at 91 days. At 56 days, the reductions in the chloride migration coefficient in comparison to the control mixture were $18 \%$ for GS1-10 and $78 \%$ for GS1-20; whereas at 91 days, these reductions were 22 and $85 \%$ for GS1-10 and GS1-20, respectively. This evolution can be attributed to the mechanism of pore-filling. Furthermore, the use of ground glass sludge waste in the contents of 10 and $20 \%$ (GS2-10 and GS220) provided improvements in chloride resistance comparable to those caused using metakaolin.

Thus, it can be confirmed, just as previous studies [11,12,15] that have used the RMT test (NT BUILD 492 [42]), that the glass powder use as a cement replacement at $20 \%$ content provides an improvement in chloride penetration resistance, mainly at 56 days. This delayed influence in the improvement of concrete microstructure can be attributed to the pozzolanic effect or to the pore-filling effect. For the control mixture, no variation in chloride resistance from 56 to 91 days is noted, whereas for the glass sludge and metakaolin mixtures, increases in chloride resistance are observed.

Pignaton [25] performed a microstructural analysis in concrete containing a glass sludge waste equivalent to the one used in this study at similar replacement contents; but without grinding the waste. The analysis focused on assessing the interfacial transition zones between the coarse aggregate and the cement paste after
28 days age. It was noted that the partial replacement of cement by GS1 at $20 \%$ content provided a reduction in the cement matrix porosity and the interfacial transition zones were reinforced by crystalline formations due to the chemical reaction with the glass powder in the hydration process. Furthermore, the concrete have not presented any cracking that could indicate the production of expansive gel or ASR.

This study assessed the microstructure of concrete with the ground waste (GS2) and metakaolin (ME) focusing on the improvement of the interfacial transition zone between cement paste and aggregate (Figure 10). 500x, 1000x and 3000x enlargements were used. The scanning electron microscope (SEM) images (Figure 10) shows that the mixtures with GS2 and ME presents a more compact structure with fewer pores in relation to the REF. The formation of fibrous C-S-H crystals filling the pores among the hydrated cement particles is verified, explaining the improvement in the durability properties of the mixtures. In the GS2-2- and ME-20 mixtures, the GS2 and ME particles were encapsulated and dispersed in the gel hydrated compounds (Figure $10 \mathrm{f}$ and 10i). Furthermore, no cracking due to the possible expansive reaction of the waste glass was found.

\subsection{Bulk diffusion test (BDT)}

Figure 11 presents the linear regression analysis of the chloride content through the concrete depths, from the diffusion by immersion test according to NT BUILD 443 [43]. The use of GS1 and GS2 provided a reduction in the chloride content through the concrete, and these reductions are greater for increased contents of glass powder (Figure 11a and 11b). In Figure 11c, by analyzing the mixtures with glass powder at $20 \%$ content (GS1-20 and GS2-20), the grinding presented itself as a determinant factor, the ground waste being

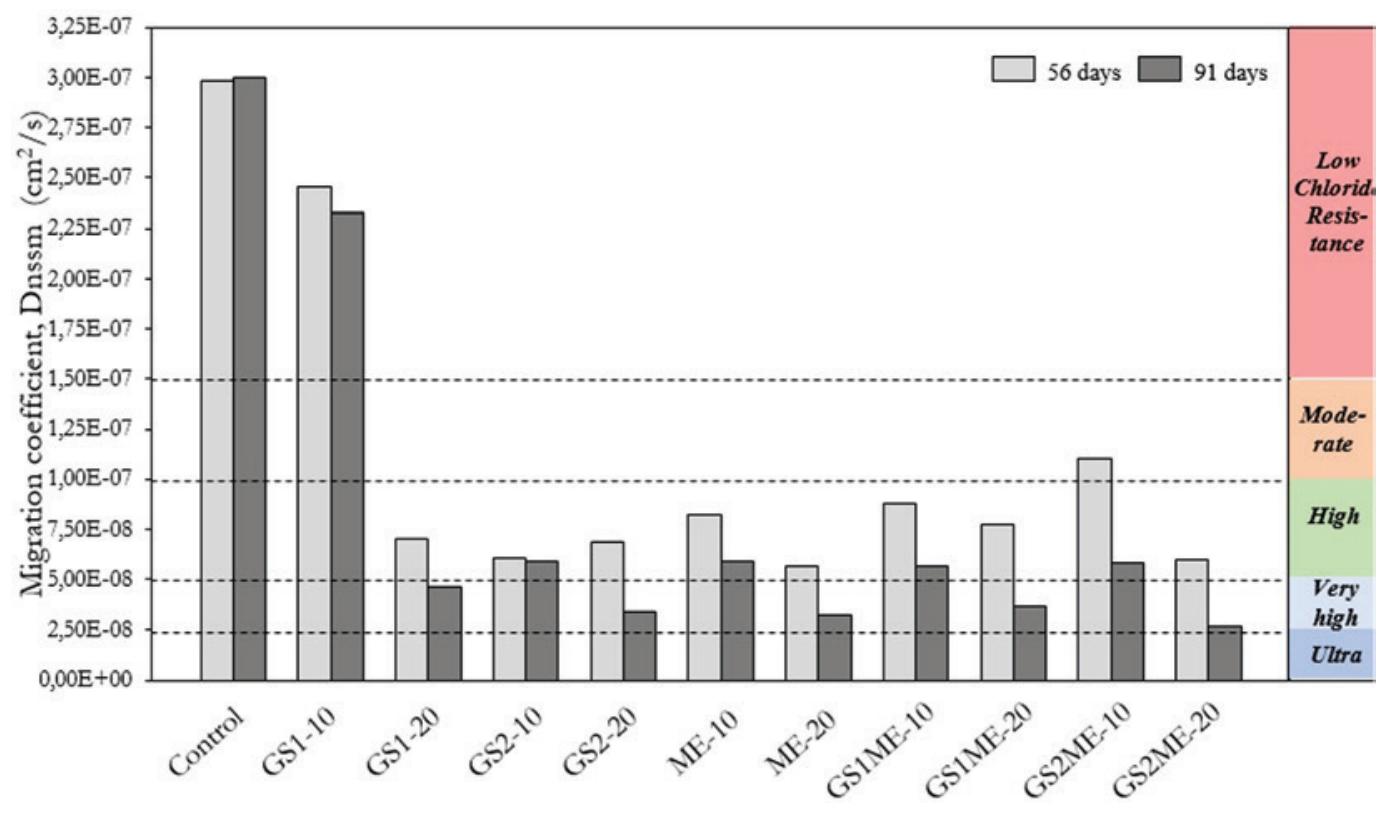

Figure 9

Non-steady-state chloride migration coefficient and chloride resistance classification 
REF 700 davs 500 times enlarged

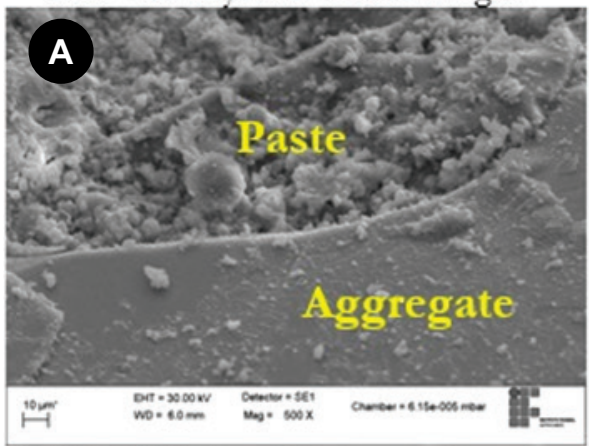

GS2-20 700 days 500 times enlarged

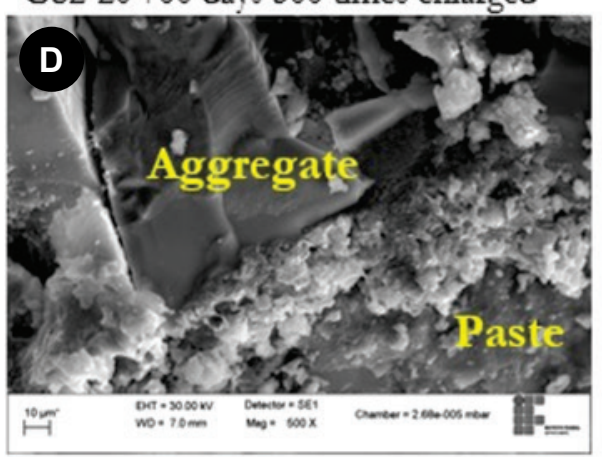

ME-20 700 days 500 times enlarged

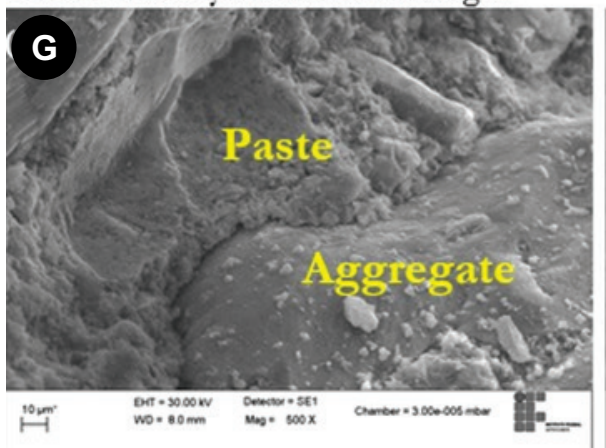

REF 700 davs 1000 times enlarged

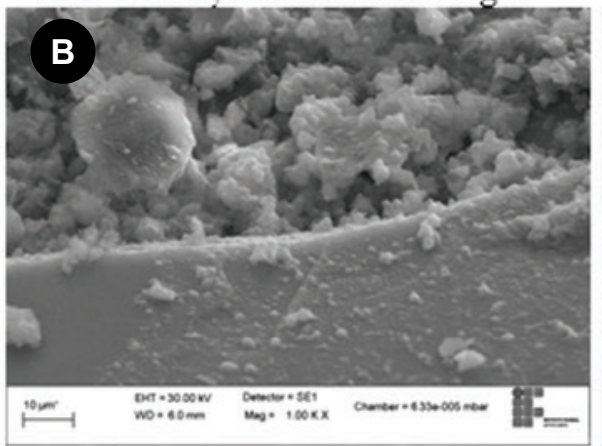

GS2-20 700 days 1000 times enlarged

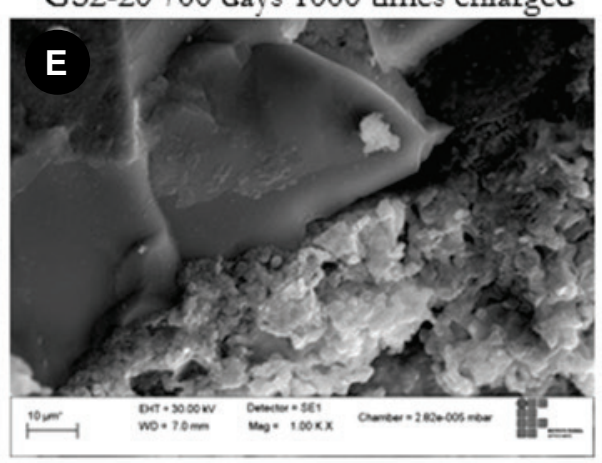

ME-20 700 days 1000 times enlarged

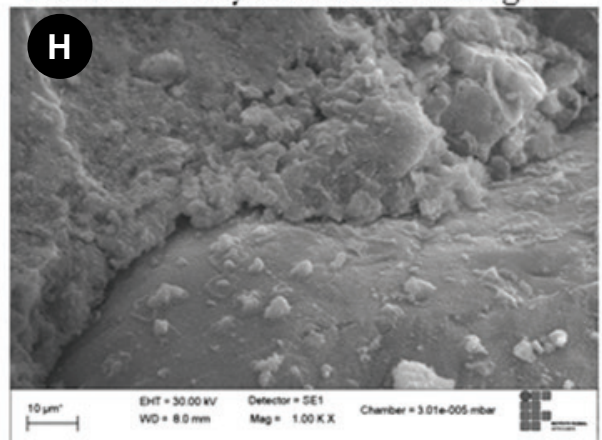

REF 700 dars 3000 times enlarged

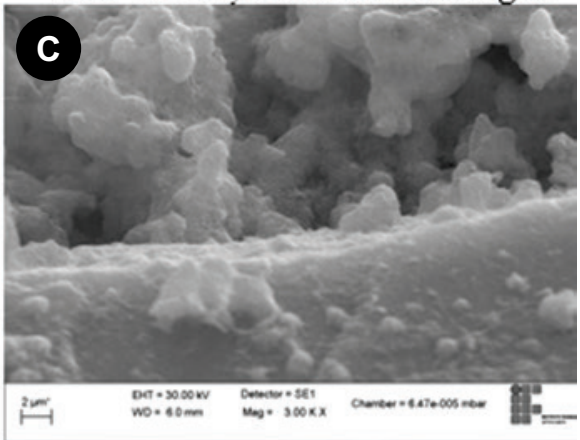

GS2-20 700 days 3000 times enlarged

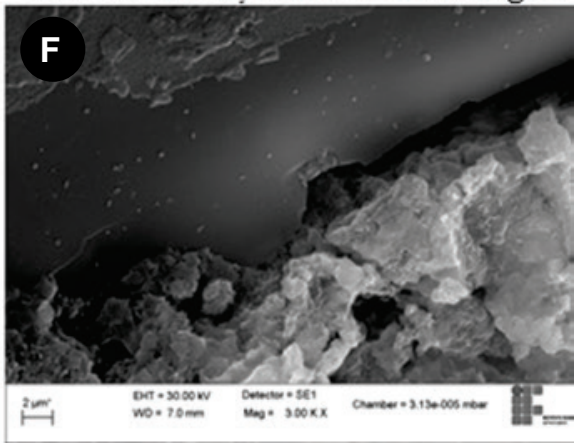

ME-20 700 days 3000 times enlarged

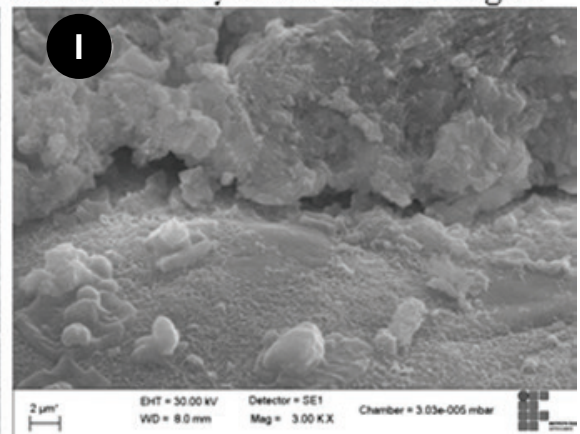

\section{Figure 10}

Microstructure analysis of concrete mixtures with GS2 and ME. (a) REF (500x magnification);

(b) REF (1000x magnification); (c) REF (5000x magnification); (d) GS2-20 (500x magnification);

(e) GS2-20 (1000x magnification); (f) GS2-20 (5000x magnification); (e) ME-20 (500x magnification);

(f) ME-20 (1000x magnification); (g) ME-20 (5000x magnification)

more efficient for chloride resistance.

From the liner regression analysis, it was possible to calculate the diffusion coefficients identified in Figure 12, as defined in NT BUILD 443 [43]. For comparative purposes, Figure 12 also presents the results of chloride diffusion coefficients obtained from NT BUILD 492 [42] test for the age of 56 days. Additionally, the limits for the qualitative assessment proposed by Gjørv [50] are also presented. From the test results of chloride diffusion (NT BUILD 443 [43]) and migration (NT BUILD 492 [42]), it is verified that the use of glass powder and metakaolin provided an increase in chloride resistance, especially in the mixtures using the ground glass powder and 10 and $20 \%$ (GS2-10 and GS2-20). Additionally, the GS2 pro- vided similar values to those of metakaolin. The GS2ME-20 mixture (GS2 and ME at 10\% each) presented the lowest diffusion coefficients, surpassing even the mixtures with only metakaolin. This mixture presented as very effective due to the combination of pozzolanic effect of both materials along with the pore-filling effect. According to Zibara et al. [51], the chloride diffusion through the concrete depends mainly on its microstructure and ions fixation capability. For mixtures with ordinary Portland cement, the key fixation mechanism is the formation of Friedel's salt and aluminates related complexes [52]. The anhydrous compounds of cement which react quickly with the chloride ions producing the Friedel's salt is the tricalcium aluminate (C3A). In concrete with SCM, it is 
indicated that the fixation capability is function of the aluminates content [53]. Thus, the metakaolin, by having in its chemical composition $33.10 \%$ alumina $\left(\mathrm{Al}_{2} \mathrm{O}_{3}\right)$ (Table 1), fosters the formation of $\mathrm{C}_{3} \mathrm{~A}$ compounds and helps to increase the chloride ions fixation. It was also observed that the chloride diffusion coefficients obtained from NT BUILD 443 [43] were higher than the chloride migration coefficients obtained from NT BUILD 492 [42] (Figure 14). This can be explained by the time difference of testing, where for the migration test the mixtures were cured for 56 days (concrete age with a more developed microstructure), and for the diffusion test, the specimens were cured for 28 days and then exposed 180 days to the chloride solution, providing more time for the chloride to propagate; a different adopted time frame from the used in studies that aimed at assessing the correlation between both tests [21, 23]. The BDT (NT BUILD 443) is relevant for the comparison among different concrete of the same study due to be an alternative accelerated method which do not require the use of electrical currents and the adoption of colorimetric indicators - procedures used by RMT (NT BUILD 492 [42]) which are criticized by some researchers [21-23]. From this comparison of results, it can be noted that by adopting a content of cement replacement of $20 \%$, the glass powder can be used without grinding (GS1), presenting increases in chloride penetration resistance, comparable to the values obtained in the mixtures with metakaolin use. Moreover, this chloride resistance can be further increased if the waste is ground (GS2).

3.6 Alkali-silica-reaction (ASR) -

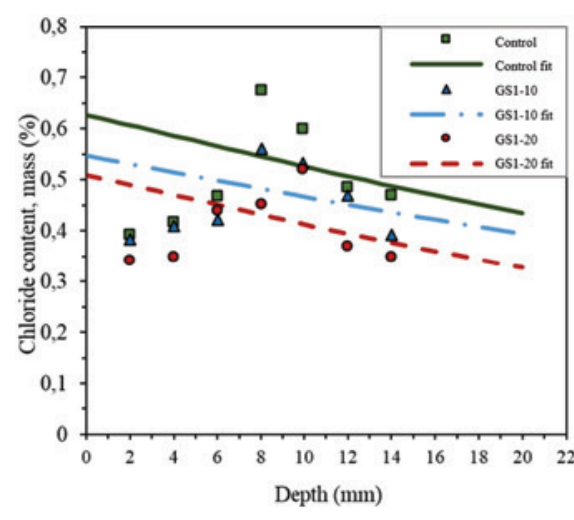

(a)

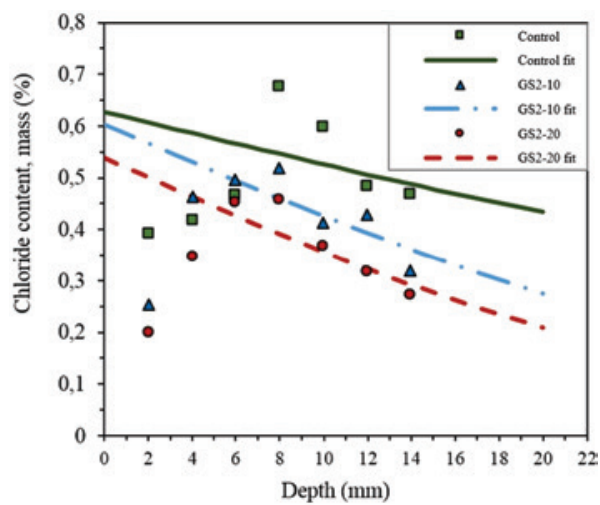

(b)

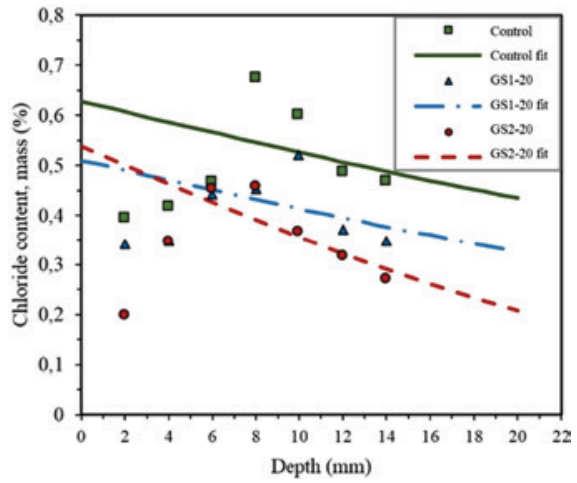

(c)

Figure 11

Linear regression analysis of chloride content through concrete depths. (a) Glass sludge waste without grinding (GS1); (b) Ground glass sludge waste (GS2); (c) GS1 and GS2 at 20\% content

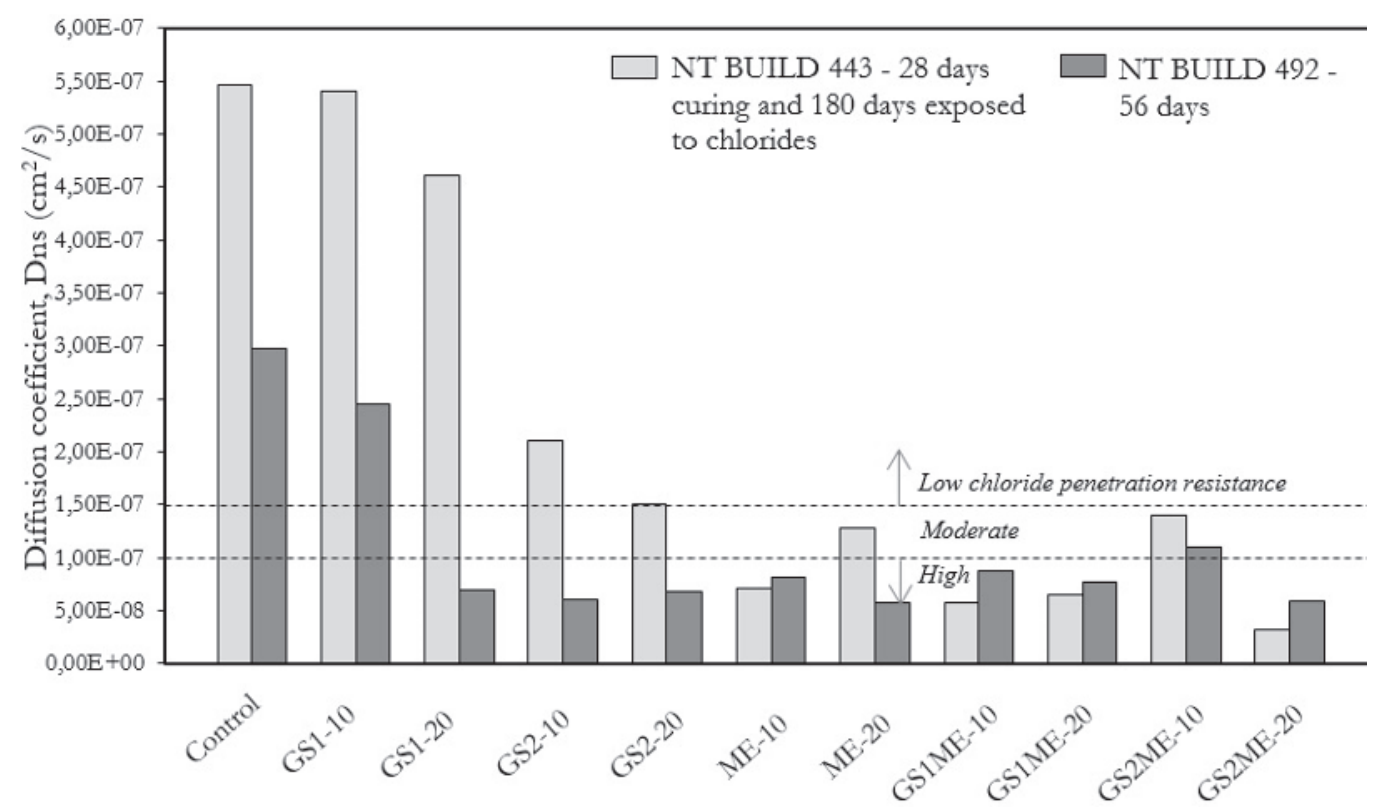

Figure 12

Chloride diffusion coefficient results as according to NT BUILD 443 and NT BUILD 492 


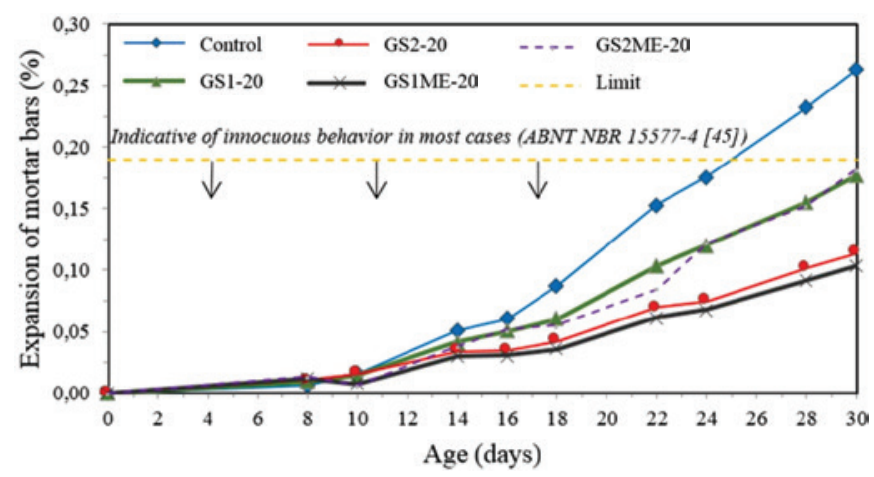

Figure 13

Expansion of mortar bars produced with waste glass and metakaolin

\section{Expansion measurement}

The expansion results of mortar bars immersed for 30 days, as according to ABNT NBR 15577-4 [45], can be seen in Figure 13. It its verified that the glass powder, despite presenting a greater quantity of available alkalis than is required by the standard to be classified as a pozzolanic material, did not cause an increase in ASR related expansion. In fact, there was a reduction in the expansion due to the use of glass powder, and this was more prominent in the GS2. This behavior supports the results from other studies [16, 19], which stated that the glass powder, as a function of its particle dimensions, can cause a mitigation of ASR in concrete. According to Shayan and $\mathrm{Xu}$ [16], the use of glass microparticles tends to inhibit the ASR, thereby indicating that the quantity of available alkalis in the glass powder does not necessarily contribute to ASR. This is explained by the encapsulation of alkalis in the paste, which are unable to react. Additionally, the high silica content is circumvented by the fact that the high surface area and the amorphous state of the glass induced the silica to react with the calcium hydroxide in the early ages. Thus, there was not enough silica in advanced ages for further reactions. Furthermore, the GS1ME-20 favored the reduction of the ASR related expansive behavior. According to Matos and Sousa-Coutinho [12], the use of SCM can reduce the deleterious effect of the expansion caused by ASR. This is attributed to the reduction of calcium hydroxide concentration in the pores solution, due to pozzolanic reactions, resulting in a densification of the microstructure, fostering lower alkali mobility and quantity in the pores solution.

\section{Conclusions}

1. The mixtures containing glass sludge waste presented a reduction in workability in comparison with the control mixture, further noticed with increase of the content. Nevertheless, the slump values were higher than the mixtures containing only metakaolin.

2. The use of glass waste, originated from stoning and polishing of glass, generally did not cause a reduction in compressive strength with statistical significance (with exception to the glass without grinding at 20\%, GS1-20), and provided durability improvements. The resistance to chloride penetrability was im- proved, evidenced by chloride ions diffusion and migration tests. Additionally, the ASR potential was reduced by using the glass powder, and further diminished by grinding the glass waste.

3. Many advantages in incorporating the ground glass sludge waste as a cement replacement at $20 \%$ (GS2-20) were verified. Its use did not cause significant influence on compressive strength and provided significant improvements in chloride penetration resistance. The reductions obtained in comparison with the control mixture were $80 \%$ in total charge passed, $89 \%$ in chloride migration coefficient, $73 \%$ in chloride diffusion coefficient and $58 \%$ in ASR related expansion.

4. The combined use of metakaolin and ground glass sludge waste at $10 \%$ each (GS2ME-20) presented the best performance among the mixtures which contained glass sludge waste, providing more than $12 \%$ increase in compressive strength and more than $74 \%$ reduction in chloride penetrability. It can also be an alternative to the isolated use of metakaolin (ME-20), since equivalent values of compressive strength and chloride resistance were observed. Thus, financial and environmental benefits may be attained.

5. This study concludes that the incorporation of ground glass sludge waste, a waste from the process of stoning and polishing of glass, can be adopted in reinforced concrete structures without detriments in the mechanical properties and providing an increase in durability in structures in an urban maritime environment. The material can replace the cement up to $20 \%$, without affecting the compressive strength at 28 days, and reducing the chloride penetration by up to $90 \%$, besides providing a reduction in ASR-related expansion.

\section{Acknowledgements}

This work was supported by the Coordination for the Improvement of Higher Education Personnel (CAPES). The authors would like to express their sincere thanks to LEMAC-UFES (Building Materials Tests Laboratory) and IFES for the testing equipment and to the companies Holcim, Viminas and Metacaulim do Brasil for providing the cement, waste glass and metakaolin, respectively, used in this study.

\section{References}

[1] A. André, J. Brito, A. Rosa, D. Pedro, Durability performance of concrete incorporating coarse aggregates from marble industry waste, J. Clean. Prod. 65 (2014) 389-396. D.F. Aponte, M. Barra, E. Vàzquez, Durability and cementing efficiency of fly ash in concrete. Constr. Build. Mater. 30 (2012) 537-546.

[3] M.C. Bignozzi; A. Saccani, L. Barbieri, I. Lancelloti, Glass waste as supplementary cementing materials: The effects of glass chemical composition, Cem. Concr. Compos. 55 (2015) 45-52.

[4] T. Gupta, S. Chaudhary, R.K. Sharma, Mechanical and durability properties of waste rubber fiber concrete with and without silica fume, J. Clean. Prod. 112 (2016) 702-711.

[5] L. Bernstein et al., Chapter 7: Industry, in: B. Metz et al. 
(Eds.), Climate Change 2007: Mitigation-Contribution of Working Group III to the Fourth Assessment Report of the Intergovernmental Panel on Climate Change, Cambridge University Press, Cambridge, United Kingdom and New York, USA, 2007, pp. 447-496.

[6] C. Shi, K. Zheng, A review on the use of waste glasses in the production of cement and concrete, Resour. Conserv. Recycl. 52 (2007) 234-247.

[7] Y. Jani, W. Hogland, Waste glass in the production of cement and concrete - A review, J. Environ. Chem. Eng. 2 (2014) 1767-1775.

[8] M. Saito, M. Shukuya, Energy and material use in the production of insulating glass windows, Sol. Energy 58 (1996) 247-252.

[9] A.M. Matos, Estudo de argamassas com substituição parcial de cimento por resíduos de vidro moídos, Engineering School, Universidade do Porto, Porto, Portugal (2010). (In Portuguese)

[10] R. Nassar, P. Soroushian, Strength and durability of recycled aggregate concrete containing milled glass as partial replacement for cement, Constr. Build. Mater. 29 (2012) 368-377.

[11] M. Kamali, A. Ghahremaninezhad, Effect of glass powders on the mechanical and durability properties of cementitious materials, Constr. Build. Mater. 98 (2015) 407-416.

[12] A. M. Matos, J. Souza-Coutinho, Durability of mortar using waste glass powder as cement replacement. Constr. Build. Mater. 36 (2012) 205-215.

[13] N. Schwarz, H. Cam, Influence of fine glass powder on the durability characteristics of concrete and comparison to fly ash, Constr. Build. Mater. 30 (2008) 486-496.

[14] J. Cassar, J. Camiller, Utilization of imploded glass in structural concrete, Constr. Build. Mater. 29 (2012) 299-307.

[15] J.A. Jain, N. Neithalath, Chloride transport in fly ash and glass powder modified concrete - Influence of test methods on microstructure, Cem. Concr. Compos. 32 (2010) 148-156.

[16] A. Shayan, A. Xu, Performance of glass powder as a pozzolanic material in concrete: a field trial on concrete slabs, Cem. Concr. Res. 36 (2006) 457-68.

[17] A. Khmiri, B. Samet, M. Chaabouni, A cross mixture design to optimise the formulation of a ground waste glass blended cement, Constr. Build. Mater. 28 (2012) 680-686.

[18] W. Jin, C. Meyer, S. Baxter, "Glascrete" - concrete with glass aggregate, Am. Concr. Inst. Mater. J. 97 (2000) 208-213.

[19] K. Hwee, H. Du, Use of waste glass as sand in mortar: Part II -Alkali-silica reaction and mitigation methods, Cem. Concr. Compos. 35 (2013) 118-126.

[20] A.M. Matos, T. Ramos, S. Nunes, J. Souza-Coutinho, Durability Enhancement of SCC with Waste Glass Powder, Mater. Res. 19 (2016) 67-74.

[21] D. Henry, V. Baroghel Bouny, T. Chaussadent, Evaluation of chloride penetration into concrete by various methods, Proceeding of the Second International RILEM Workshop on Testing and Modelling the Chloride, Paris, France,
2000, pp. 471-486.

[22] T. Luping, H.E. Sørensen, Evaluation of the Rapid Test Methods for Measuring the Chloride Diffusion Coefficients of Concrete, NORDTEST Project No 1388-98, Swedish National Testing and Research Institute Building Technology, 1998.

[23] T. Luping, H.E. Sørensen, Precision of the Nordic test methods for measuring the chloride diffusion/migration coefficients of concrete, Mater. Struct. 34 (2001) 479-485.

[24] J. Kim, J.-H. Moon, J.W. Shim, J. Sim, H.-G. Lee, G. $\mathrm{Zi}$, Durability properties of a concrete with waste glass sludge exposed to freeze-and-thaw condition de-icing salt. Constr. Build. Mater. 66 (2014) 398-402.

[25] A.A. Pignaton, Potencialidades do aproveitamento do resíduo de estação de tratamento de efluentes do processo de lapidação do vidro sodo - cálcico na produção de concretos, Technological Center, Universidade Federal do Espírito Santo, Vitória, Brazil (2012). (In Portuguese)

[26] H. Lee, A. Hanif, M. Usman, J. Sim, H. Oh, Performance evaluation of concrete incorporating glass powder and glass sludge wastes as supplementary cementing material, Journal of Cleaner Production, 170 (2018) 683-693

[27] P. Chindaprasirt, C. Jaturapitakkul, T. Sinsiri, Effect of fly ash fineness on compressive strength and pore size of blended cement paste, Cem Concr Compos 27 (2005) 425-428.

[28] H. Jun-yuan, B.E. Scheetz, Della M. Roy, Hydration of fly ash-Portland cements, Cem Concr Res 14 (1984) 505-512.

[29] Associação Brasileira de Normas Técnicas, ABNT NBR 12653: Materiais Pozolânicos - Especificação, Rio de Janeiro, Brazil. (2015). (In Portuguese)

[30] M.P. Luxán, F. Madruga, J. Saavedra, Rapid evaluation of pozzolanic activity of natural products by conductivity measurement, Cem. Concr. Res. 19 (1989) 63-68.

[31] C.S. Rodrigues, Efeito da adição de cinza de casca de arroz no comportamento de compósitos cimentícios reforçados por polpa de bambu, Pontifícia Universidade Católica do Rio de Janeiro, Rio de Janeiro, Brazil. (2004). (In Portuguese)

[32] Associação Brasileira de Normas Técnicas, ABNT NBR 5751: Materiais pozolânicos - Determinação de atividade pozolânica com cal aos sete dias, Rio de Janeiro, Brazil, 2015. (In Portuguese).

[33] Associação Brasileira de Normas Técnicas, ABNT NBR 5752: Materiais pozolânicos — Determinação do índice de desempenho com cimento Portland aos 28 dias, Rio de Janeiro, Brazil, 2014. (In Portuguese)

[34] Associação Brasileira de Normas Técnicas, ABNT NBR 6118 NB1: projeto de estruturas de concreto - procedimento, Rio de Janeiro, Brazil, 1968, rev. 2014. (In Portuguese)

[35] American Society for Testing and Materials, Standard Practice for Making and Curing Concrete Test Specimens in the Laboratory: ASTM C 192, Philadelphia, USA, 2018.

[36] American Society for Testing and Materials, Standard Test Method for Slump of Hydraulic-Cement Concrete: ASTM C 143, Philadelphia, USA, 2015.

[37] American Society for Testing and Materials, Standard Test Method for Density (Unit Weight), Yield, and Air Content (Gravimetric) of Concrete: ASTM C 138, Phila- 
delphia, USA, 2017.

[38] Associação Brasileira de Normas Técnicas, ABNT NBR 5739: Concreto - Ensaio de compressão de corpos-de-prova cilíndricos, Rio de Janeiro, Brazil, 2018. (In Portuguese)

[39] D. Whiting, Rapid determination of the chloride permeability of concrete, Final Report Portland Cement Association, Skokie, IL, USA, 1981.

[40] American Society for Testing and Materials, Standard test method for electrical indication of concrete's ability to resist chloride ion penetration: ASTM C 1202, Philadelphia, USA, 1992.

[41] T. Luping, L. Nilsson, Rapid determination of the chloride diffusivity in concrete by applying an electrical field, Am. Concr. Inst. Mater. J. 89 (1992) 49-53.

[42] Nordtest method, Concrete, mortar and cement-based repair materials: chloride migration coefficient from nonsteady-state migration experiments: NT BUILD 492, Oslo, Norway 1999.

[43] Nordtest method, Concrete, hardened: accelerated chloride penetration, NT BUILD 443, Oslo, Norway, 1995.

[44] Nordtest method, Concrete, hardened: Chloride content by volhard titration, NT BUILD 208, Oslo, Norway, 1996.

[45] Associação Brasileira de Normas Técnicas, ABNT NBR 15577-4: Agregados - Reatividade álcali-agregado, Parte 4: Determinação da expansão em barras de argamassa pelo método acelerado, Rio de Janeiro, Brazil, 2018. (In Portuguese)

[46] Z.Z. Ismail, E.A. Al-Hashmi, Recycling of waste glass as partial replacement for fine aggregate in concrete, Waste Manag. 29 (2008) 655-659.

[47] S.B. Park, B.C. Lee, J.H. Kim, Studies on mechanical properties of concrete containing waste glass aggregates, Cem. Concr. Res. 34, (2004) 2181-2189.

[48] S. Castro, J. Brito, Evaluation of the durability of concrete made with crushed glass aggregates. J. Clean. Prod. 41 (2013) 7-14.

[49] Associação Brasileira de Normas Técnicas, ABNT NBR 8953: Concreto para fins estruturais - Classificação pela massa específica, por grupos de resistência e consistência, Rio de Janeiro, Brazil, 2015. (In Portuguese)

[50] O.E. Gjørv, Service life of concrete structures and performance-based quality control, International Workshop on Innovations in Concrete Materials, Whistler, Canada, 2001, 13 p.

[51] H. Zibara, R.D. Hooton, M.D.A. Thomas, K. Stanish, Influence of the $\mathrm{C} / \mathrm{S}$ and $\mathrm{C} / \mathrm{A}$ ratios of hydration products on the chloride ion binding capacity of lime-SF and lime-MK mixtures, Cem. Concr. Res. 38 (2008) 422-426.

[52] N. Saikia, S. Kato, T. Kojima, Thermogravimetric investigation on the chloride binding behaviour of MK-lime paste, Thermochimica Acta 444 (2006) 16-25.

[53] R. Talero, L. Trusilewicz, A. Delgado, C. Pedrajas, R. Lannegrand, V. Rahhal, Comparative and semi-quantitative $\mathrm{XRD}$ analysis of Friedel's salt originating from pozzolan and Portland cement, Constr. Build. Mater. 25 (2011) 2370-80. 